\title{
Spajanie laserowe z materiałem dodatkowym i mechanicznym układem śledzenia złącza
}

\author{
Laser joining with wire filler material \\ and mechanical seam tracing system
}

\section{Streszczenie}

Przedstawiono dotykowy (taktylny) system śledzenia styku złącza w przypadku zrobotyzowanego spawania laserowego ze spoiwem w postaci drutu i lutospawania na przykładzie wykorzystania głowicy Scansonic ALO3. Opisano konstrukcje, i system sterowania takim stanowiskiem zbudowanym w oparciu o laser dyskowy i robot przemysłowy. Zbadano wpływ podstawowych parametrów systemu śledzenia przy spawaniu i lutospawaniu złączy zakładkowych o grubości do $2 \mathrm{~mm}$.

\section{Wstęp}

Procesy spajania laserowego ze spoiwem stosuje się obecnie najczęściej do łączenia cienkościennych konstrukcji, których elementy składowe są uzyskiwane takimi technologiami, jak: cięcie nożycami, wykrawanie, wyoblanie, głębokie tłoczenie. Przy masowej produkcji technologie te oraz sposób montażu przed spawaniem łączonych elementów (np. w przypadku spajania elementów karoserii samochodowych, różnego rodzaju obudów, pojemników, elementów paneli i stelaży wykonanych z cienkościennych elementów) nie zawsze są w stanie zapewnić odpowiednią

Prof. dr hab. inż. Jan Pilarczyk, dr inż. Marek Banasik, dr inż. Sebastian Stano, mgr inż. Jerzy Dworak - Instytut Spawalnictwa, Gliwice. powtarzalność i dokładność przygotowania styku oraz pozycjonowania elementów do spawania, tak aby opracowany na wzorcowym elemencie program sterowania maszyną CNC lub program sterowania robota zapewniał, w przypadku każdego elementu z serii, odpowiednio dokładne prowadzenie wiązki i materiału spoiwa dokładnie wzdłuż trajektorii krawędzi styku. Jednocześnie od tego typu złączy żąda się wysokiej jakości i estetyki wykonania.

Jedną z metod "elastycznego" dostosowania zaprogramowanej trajektorii spajania do trajektorii rzeczywistej jest opracowany w ostatnich latach taktylny (dotykowy) system śledzenia złącza. Zalety procesu spajania laserowego ze spoiwem i taktylnym systemem śledzenia złącza umożliwiają znacznie szersze przemysłowe wykorzystanie spajania z użyciem lasera.

W artykule przedstawiono ideę oraz zalety i ograniczenia tej metody przy wykorzystaniu spoiwa w postaci drutu i lasera dyskowego jako źródła ciepła w procesie spawania. 


\section{Technologia spajania laserem ze spoiwem w postaci drutu}

Schemat i podstawowe parametry procesu spajania laserem ze spoiwem w postaci drutu na przykładzie spajania złączy zakładkowych przedstawiono na rysunku 1.

Proces spajania ze spoiwem wymaga wiązki o odpowiednio wysokim poziomie mocy, ponieważ ciepło wynikające z oddziaływania wiązki laserowej musi zostać zużyte na stopienie materiału dodatkowego oraz odpowiednie nagrzanie (w przypadku procesu lutospawania) lub przetopienie (w przypadku procesu spawania) materiału rodzimego, a pole powierzchni przekroju poprzecznego spoiny jest większe w porównaniu do pola spoin otrzymywanych klasyczną metodą spawania laserowego z głębokim przetopieniem. Poziom mocy w przypadku nowoczesnych laserów na ciele stałym (dyskowych i włóknowych) jest znacznie większy niż klasycznych, dotychczas stosowanych laserów, dlatego w pełni nadają się one do procesu spawania laserowego ze spoiwem.

Pierwszym, podstawowym warunkiem uzyskania poprawnych połączeń przy spajaniu laserowym ze spoiwem jest bardzo precyzyjny dobór i zaprogramowanie wielu parametrów wzajemnie oddziałujących na siebie i na jakość połączenia (rys. 1). Drugim warunkiem jest konieczność precyzyjnego prowadzenia wiązki i drutu względem siebie oraz po trajektorii styku.

Proces spajania laserowego ze spoiwem można prowadzić z wykorzystaniem specjalnych głowic. Rozwiązania konstrukcyjne i możliwości technologiczne takich głowic decydują o rodzaju i parametrach połączeń, jakie można uzyskać.

Głowica robocza do spawania lub lutospawania laserowego ze spoiwem oprócz układu ogniskującego

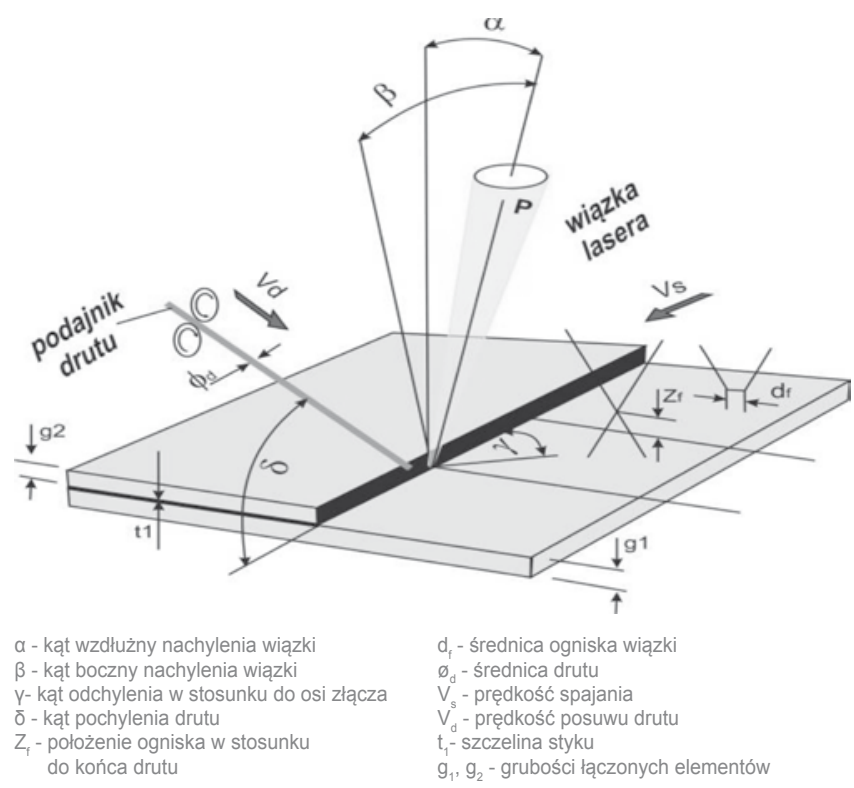

Rys. 1. Parametry procesu spajania laserem ze spoiwem w postaci drutu

Fig. 1. Laser joining with wire filler material parameters wiązke laserową zawiera zintegrowany precyzyjny moduł prowadzenia i pozycjonowania końcówki drutu w obszarze spajania. Niestabilność podawania drutu i zmiany położenia jego końcówki mogą skutkować brakiem stabilności procesu i pojawieniem się lokalnych niezgodności, a w skrajnym przypadku lokalnym brakiem połączenia. Dlatego stosowane są układy podawania drutu typu push-pull, zapewniające odpowiednią stabilność podawania drutu, z kompletem wymiennych rolek, które są przystosowane do podawania standardowych drutów spawalniczych różnych gatunków, zwykle o średnicach 1,0; 1,2; 1,6 mm.

Poszczególne konstrukcje głowic laserowych przeznaczonych do spajania laserowego ze spoiwem różnią się między sobą sterowaniem i sposobem integracji układu podawania materiału dodatkowego oraz wyposażeniem dodatkowym (np. kamera CCD ułatwiająca programowanie trajektorii spajania, systemy monitorowania procesu, urządzenia antykolizyjne, zintegrowane lub niezależne dysze nadmuchu gazu ochronnego, układ cross-jet chroniący optykę głowicy przed odpryskami materiału z ciekłego jeziorka, układy kolimacyjne głowicy $z$ serwomotorami, umożliwiające programową zmianę ustawienia położenia ogniska wiązki laserowej itp). Budowane są również głowice uniwersalne umożliwiające spajanie laserowe $z$ materiałem dodatkowym i spawanie hybrydowe laser + MIG.

Tak duża liczba funkcji oraz elementów wymagających odpowiedniego wysterowania w procesie spajania powoduje, że dużym wyzwaniem pod względem budowy np. stanowiska zrobotyzowanego czy urządzenia ze sterowaniem CNC i zapewnienia funkcjonalności wszystkich jego modułów, jest połączenie głowicy $z$ robotem i laserem $w$ jedno działające uniwersalne stanowisko, na którym będzie możliwość realizacji zaplanowanych procesów technologicznych. Przy wyborze głowic technologicznych do określonego procesu spajania oprócz parametrów technicznych, związanych z samym procesem, należy także uwzględnić możliwości wzajemnego dopasowania układów mechanicznych, układów sterowania i interfejsów głowicy $\mathrm{z}$ innymi komponentami stanowiska zrobotyzowanego czy modułu linii produkcyjnej.

Najbardziej zaawansowane konstrukcje głowic mają własne systemy programowania i sterowania oraz mogą mieć zintegrowane systemy adaptacyjne śledzenia złącza.

\section{Badania i przykłady zastosowań taktylnego systemu śledzenia złącza przy zrobotyzowanym spajaniu laserem dyskowym}

Ideę systemu i sposób sterowania taktylnym układem śledzenia złącza w czasie spawania laserowego ze spoiwem w postaci drutu można zobrazować na przykładzie wykorzystania głowicy ALO3 firmy 


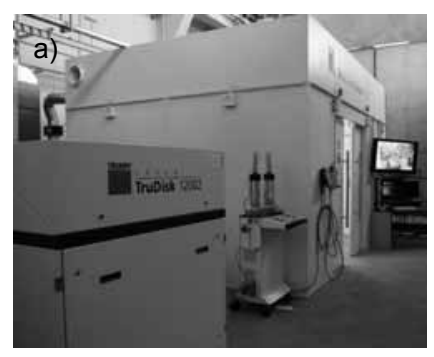

c)

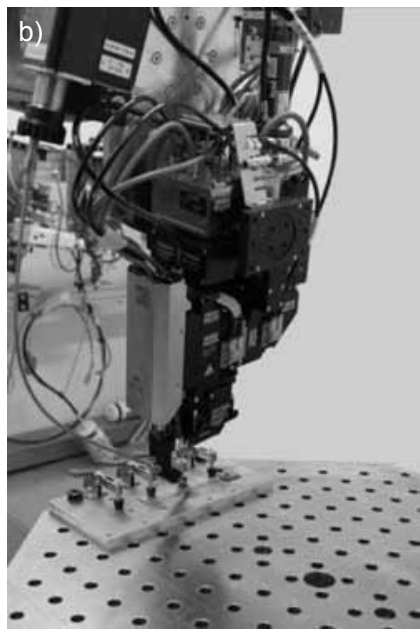

1 - zakres programowalny ustawienia sił i limitów bezpieczeństwa, w którym będzie pracować system taktylnego śledzenia 2 - limit sprzętowy $-110^{\circ}$ (napę+d silników)

3 - teoretycznie możliwy zakres odchylenia głowicy umożliwiający pracę głowicy w pozycjach przymusowych, np. w miejscach trudno dostępnych

Rys. 2. Zrobotyzowane stanowisko do spawania i cięcia laserowego z laserem dyskowym o mocy $12 \mathrm{~kW}$ : a) widok lasera i kabiny ochronnej, b) głowica ALO3 do spajania laserowego z materiałem dodatkowym w postaci drutu i taktylnym układem śledzenia złącza, c) zakres regulacji osi uchylnej głowicy

Fig. 2. Robotic stadion for laser welding and cutting using $12 \mathrm{~kW}$ disk laser: a) the view of laser and cabine, b) ALO3 head for laser welding with filler material and seam tracing system, c) the axis of head manipulation range

Scansonic we współpracy z robotem przemysłowym i laserem dyskowym. Takie stanowisko zostało stworzone w Instytucie Spawalnictwa w Gliwicach (rys. 2).

Głowica ALO3 firmy Scansonic jest nowoczesną głowicą spawalniczą umożliwiającą spajanie laserowe $z$ materiałem dodatkowym w postaci drutu $z$ dotykowym systemem śledzenia styku złącza (rys. 2b). Aktualnie w światowym przemyśle pracuje jedynie kilkanaście takich głowic, $w$ większości na liniach technologicznych w przemyśle samochodowym, gdzie są wykorzystywane do lutospawania elementów karoserii lub innych komponentów, przy łączeniu których wymagane jest wykonanie precyzyjnych złączy o wysokiej estetyce i jakości.

Oprócz komponentów optycznych, które kształtują wiązkę laserową, głowica ALO3 jest wyposażona w niezależny układ sterowania, serwonapędy oraz czujniki umożliwiające wykorzystanie końcówki drutu jako mechanicznego, taktylnego systemu śledzenia złącza [3].

Konstrukcja głowicy umożliwia:

- bardzo dokładne i powtarzalne ustawienie osi uchylnej (optyki ogniskującej ze zintegrowanym układem podawania drutu) w zakresie $\pm 110^{\circ}$ przez programowe ustawienie położenia serwonapędów osi uchylnej oraz regulację prądu utrzymującego zadaną pozycję, co umożliwia prowadzenie procesu spawania w pozycjach przymusowych lub miejscach trudno dostępnych (rys. 2c);

- programową regulację położenia ogniska wiązki laserowej względem końcówki drutu (wyskalowana
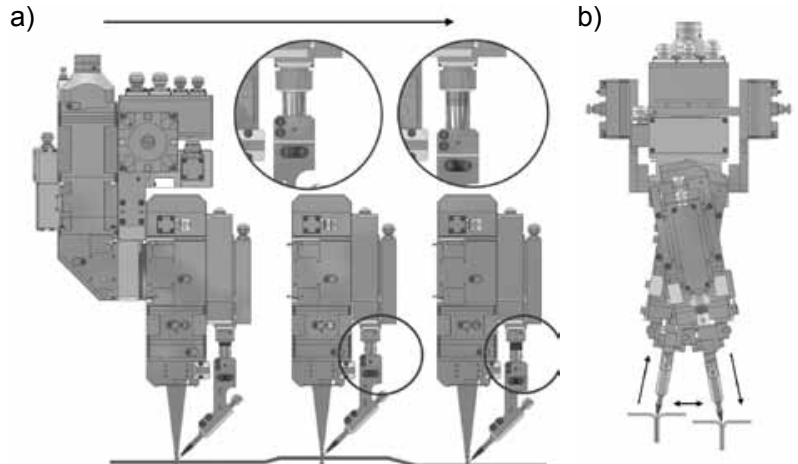

Rys. 3. Możliwości regulacji i taktylnego śledzenia styku złącza głowicy Scansonic ALO3: a) adaptacja końcówki drutu i ogniska w osi liniowej (LA), b) adaptacja końcówki drutu i ogniska z wykorzystaniem osi uchylnej (SA) i osi liniowej (LA) [3]

Fig. 3. The possibilities of regulation and Scansonic ALO3 seam tracing system: a) adaptation of the wire end and the outbreak of the linear axis (LA), b) adaptation of the wire end and focus using tilt (SA) and the linear axis (LA) [3] a)

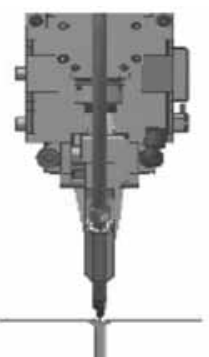

b)

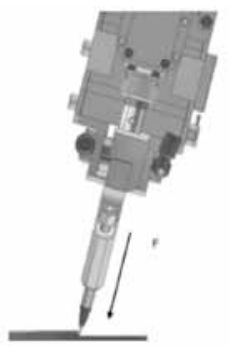

c)

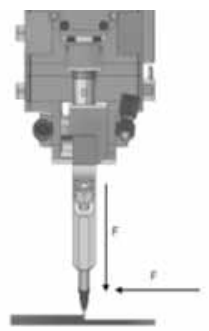

Rys. 4. Możliwe warianty ustawienia głowicy ALO3 przy wykonywaniu różnych rodzajów złączy: a) swobodne przemieszczanie końcówki drutu w złączu przylgowym; b, c) warianty ustawienia sił docisku przy spawaniu złączy zakładkowych [3]

Fig. 4. Possible options of setting ALO3 head with different types of welds: a) the free movement of the tip of the wire in the joint edge; b, c) options for setting the clamping force in welding lap joints [3]

wartość w mm w zależności od zmiany położenia kolimatora wzdłuż osi wiązki laserowej), pozwalającą uzyskać odpowiednią średnicę plamki wiązki laserowej w obszarze końcówki drutu (w obszarze oddziaływania wiązki laserowej na drut i łączony materiał);

- przemieszczanie się ramienia teleskopu z podajnikiem drutu wzdłuż osi prostopadłej do powierzchni materiału wraz $z$ utrzymaniem stałej wartości położenia ogniska wiązki względem końcówki drutu (w zakresie +/- $5 \mathrm{~mm}$ - rys. 3a) - utrzymanie stałej wartości średnicy plamki wiązki laserowej w obszarze oddziaływania wiązki laserowej na drut i łączony materiał;

- swobodne przemieszczanie się ramienia głowicy zgodnie z siłami działającymi na końcówkę drutu - drut prowadzony jest przez rowek spoiny (mechanizm wykorzystywany np. podczas spawania złączy równoległych - rys. 3b, 4a);

- pojawienie się siły działającej na drut w kierunku prostopadłym do osi złącza i drutu - wykorzystywane w przypadku spawania złączy zakładkowych (drut jest zawsze dociskany do krawędzi - rys. 4c). 
Głowica ALO3 ma własny niezależny układ sterowania Scapacs, który jest połączony i komunikuje się (wzajemne przesyłanie sygnałów i potwierdzeń - out/ in) z systemem sterowania robota KRC2 z wykorzystaniem protokołu Profibus (rys. 5). Parametry związane ze zmianą układu kolimacji w osi z (LA - linear axis) - zachowanie stałej średnicy plamki ogniska wiązki na końcówce drutu i osi uchylnej (SA swivel axis) oraz zakres ich regulacji mogą być programowane i przechowywane w układzie elektronicznym wbudowanym w głowicę. Służy do tego celu specjalne niezależne oprogramowanie HMI-B zainstalowane na komputerze stacjonarnym lub laptopie, który można połączyć (z wykorzystaniem protokołu sieciowego TCP) z układem sterowania Scapacs umieszczonym w głowicy (rys. 5). W układzie tym są przechowywane zestawy parametrów sił docisku, ich zakres regulacji oraz limity odchyleń i bezpieczeństwa dla poszczególnych osi.

W programie tworzonym w układzie sterowania robota do obróbki konkretnego elementu oprócz zestawu parametrów ruchu głowicy zawieszonej na kiści robota (końcówki drutu), parametrów lasera i parametrów posuwu drutu wybiera się, dla określonego odcinka złącza (w zależności od jego geometrii i potrzeb technologicznych), określony zestaw parametrów sterowania głowica, zdefiniowanych wcześniej i zapisanych w systemie sterowania Scapacs mieszczącym się w głowicy. Taki system sterowania i programowania pozwala na różnych odcinkach złącza prowadzić proces spajania z różnymi parametrami systemu śledzenia.

Procesy spawania i lutospawania laserowego ze spoiwem w warunkach produkcyjnych są obecnie

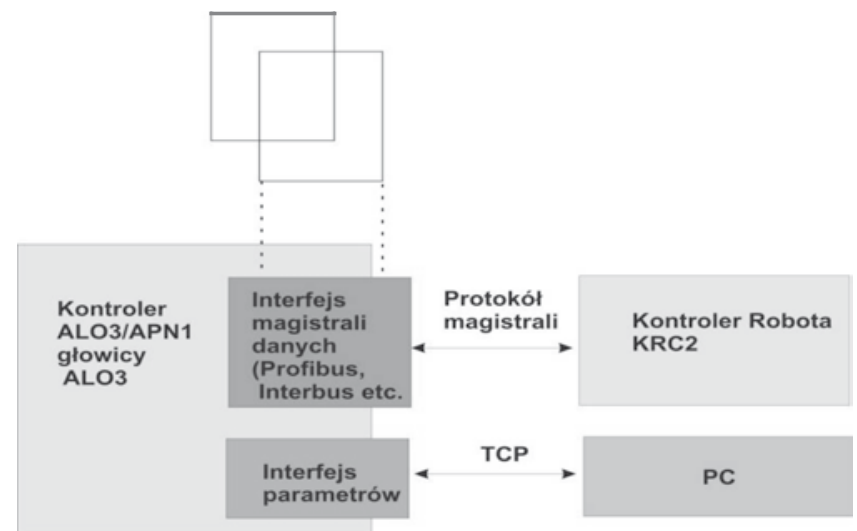

Rys. 5. Schemat ideowy połączenia głowicy ALO3 z kontrolerem robota i systemem programowania parametrów HMI

Fig. 5. The scheme of setting of head ALO3, robot controller and HMI parameter programming system

a)

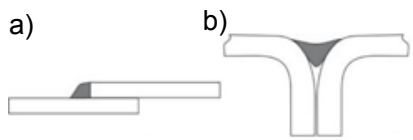

Rys. 6. Typowe złącza wykonywane metodą spajania laserowego ze spoiwem

Fig. 6. Typical laser welding with filler material joints najczęściej wykorzystywane do spajania złączy zakładkowych i równoległych, pachwinowych lub złączy ze spoinami brzeżnymi, jakie występują w precyzyjnych konstrukcjach spajanych, gdzie od złączy wymaga się wysokiej jakości, precyzji i estetyki (rys. 6).

Niezależnie od ustawień parametrów w układzie Scapacs, drut jest zawsze dociskany do powierzchni materiałów łączonych przez układ sprężynowy ramienia teleskopowego. Możliwa jest praca głowicy ze stałym położeniem ogniska wiązki lub $z$ włączonym układem nadążania za zmianami położenia drutu wzdłuż osi z (osi wiązki laserowej). Przy takim ustawieniu następuje automatyczna regulacja zmiany położenia ogniska wiązki laserowej i stałe utrzymanie średnicy plamki wiązki laserowej na końcówce drutu (rys. 3a). Jeżeli nierówności lub kształt łączonych elementów mieszczą się $w$ zakresie regulacji, możliwe jest znaczne uproszczenie programu robota. Zamiast odwzorowywać dokładnie nierówności powierzchni, wystarczy zaprogramować ruch liniowy układu pozycjonowania głowicy.

Śledzenie krawędzi złącza w płaszczyźnie prostopadłej do osi wiązki laserowej odbywa się z wykorzystaniem serwonapędów osi uchylnej (SA). Jeżeli konstrukcja złącza tworzy układ umożliwiający samoistne prowadzenie drutu, np. złącze teowe w pozycji korytkowej, złącze równoległe, możliwe jest ustawienie zerowej siły bocznej dla serwonapędów osi uchylnej (rys. 4a, 6b, 7). Głowica wtedy prowadzona jest przez opierający się drut i poddaje się zmianom położenia
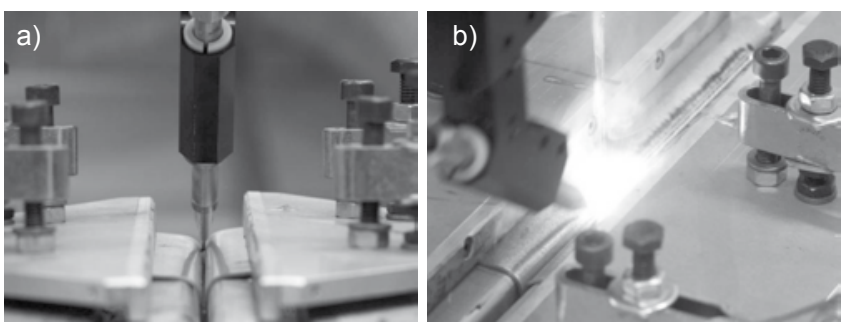

Rys. 7. a) Prowadzenie drutu w złączu przylgowym, b) proces lutospawania laserowego

Fig. 7. a) Wire supply in the joint edge, b) laser brazing process
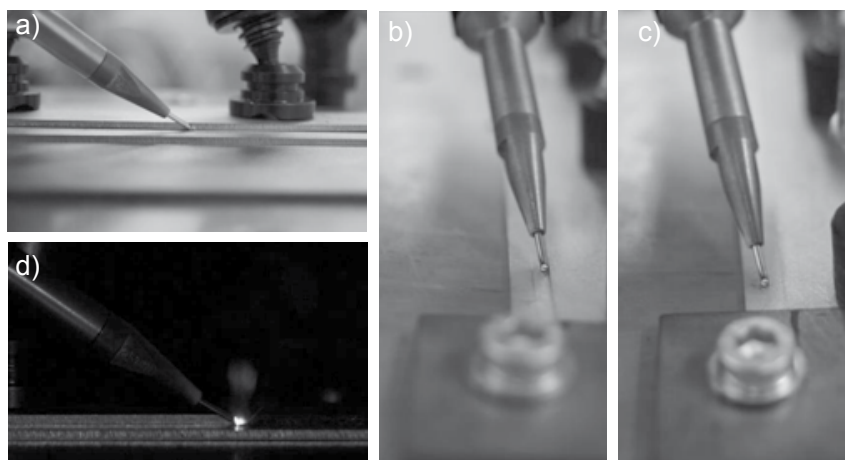

Rys. 8. Śledzenie trajektorii spawania laserowego w złączach zakładkowych z wykorzystaniem końcówki drutu: a, b) końcówka drutu dociskana do krawędzi złącza; c) końcówka drutu w początkowym punkcie złącza bez wymuszonej siły bocznej; d) proces lutospawania laserowego

Fig. 8. Seam tracking with the use of the end of the wire in the laser lap weld process: $a, b$ ) the end of wire clamping to the edge of the join, c) the end of the wire in the starting point without side clamping force, d) the laser brazing process 

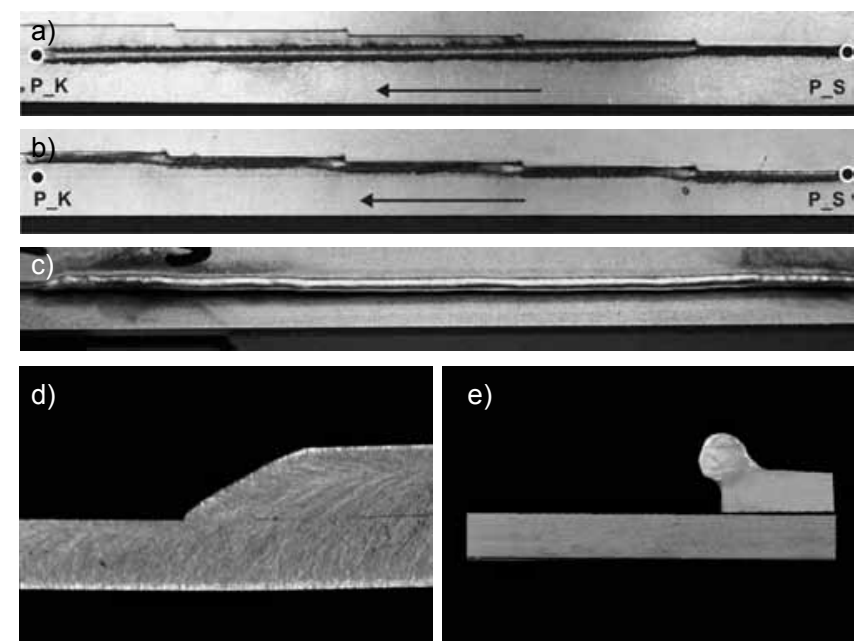

Rys. 9. Przykładowy wpływ bocznej siły docisku drutu w procesie lutospawania laserowego z zastosowaniem głowicy ALO3: a) zbyt mała wartość bocznej siły docisku; b, d) prawidłowo dobrane parametry bocznej siły docisku; c, e) zbyt duża boczna siła docisku (P_S - punkt startowy zaprogramowanej ścieżki, P K - punkt końcowy zaprogramowanej ścieżki; materiał: stal ocynkowana galwanicznie, grubość: $1 \mathrm{~mm}$, spoiwo: CuSi3Mn1, śred. - 1,2 mm)

Fig. 9. An example of a side effect of clamping force in the process of brazing using a laser head ALO3 and the wire as a filler material: a) too low side clamping force $b, d$ ) properly chosen parameters of the lateral clamping force; $c, e)$ too much side clamping force $\left(P \_S\right.$ - programmed starting point path, $\mathrm{P} \_\mathrm{K}$ - programmed path endpoint; material: galvanized steel, thickness: $1 \mathrm{~mm}$, base: CuSi3Mn1, dia. $-1.2 \mathrm{~mm}$ )

wymuszanym przez ewentualne zmiany trajektorii, pomimo zaprogramowania ruchu liniowego pomiędzy początkowym i końcowym punktem spawania.

W przypadku złączy zakładkowych możliwe jest ustawienie siły docisku drutu do krawędzi złącza (rys. 4c, 8). Dociskany drut do krawędzi złącza podąża za ewentualnymi zmianami trajektorii, a zintegrowana z ruchomym teleskopem optyka skupiająca wiązkę laserową zapewnia niezmienne położenie ustawionej plamki ogniska wiązki laserowej na końcówce topionego drutu i topienie w odpowiednim miejscu materiału dodatkowego (rys. 8d). Jeżeli przekroczony zostanie zakres regulacji urządzenia lub zakres bezpieczeństwa narzucony przez użytkownika i zapisany w systemie Scapacs, proces jest zatrzymywany i na panelu sterowania systemu pojawia się komunikat o przekroczonym zakresie położenia osi uchylnej głowicy. Narzucenie ograniczenia zakresu regulacji przez użytkownika jest o tyle istotne, że pozwala uniknąć zmian trajektorii złącza wykraczających poza przewidywany, wymagany w danej konstrukcji zakres.

Prawidłowe ustawienie wartości siły bocznego docisku, oprócz pozostałych parametrów procesu (rys. 1), jest niezmiernie istotne dla prawidłowego przebiegu procesu spajania. Dobór wartości siły bocznego docisku jest uzależniony on rodzaju prowadzonego procesu oraz oczekiwanej „czułości” regulacji. Próby ustawienia i regulacji siły docisku drutu do krawędzi bocznej prowadzone w trybie testowym (bez włączenia posuwu drutu i wiązki laserowej) są niemiarodajne. W rzeczywistym procesie, kiedy pojawia się ciekły metal, następuje zmiana układu sił działających na końcówkę drutu, związana m.in. z siłami napięcia powierzchniowego na granicy fazy ciekłej i stałej, lepkością oraz wielkością ciekłego jeziorka. Oznacza to, że raz dobrane parametry dla układu śledzenia złącza np. w procesie lutospawania laserowego nie są parametrami uniwersalnymi i w przypadku innego procesu, np. spawania laserowego, powinny one być skorygowane. Przy zbyt małej sile bocznego docisku ustawionej w systemie głowicy może zostać ona zrównoważona przez układ sił działających w obszarze utworzonego ciekłego jeziorka i wypadkowa siła docisku bocznego będzie niewystarczająca do prawidłowego procesu śledzenia złącza (rys. 9a). Zbyt duża siła docisku może spowodować przesunięcie ciekłego jeziorka na górną krawędź złącza zakładkowego (rys. 9c, e) lub nawet zupełnie poza obszar, w którym powinno zostać utworzone złącze. Szczególnie jest to widoczne w procesie lutospawania laserowego.

W przypadku spawania laserowego zakres możliwych do ustawienia wartości bocznej siły docisku jest znacznie większy i siła ta wyraźnie wpływa na kształt uzyskanej spoiny pachwinowej, w szczególności na jej symetryczność (rys. 10). W przypadku testowanych złączy zakładkowych blach ze stali nierdzewnej o grubości 2 mm zwiększenie bocznej siły docisku pozwoliło poprawić symetryczność uzyskanej spoiny pachwinowej, a także uzyskać nadtopienie górnej krawędzi złącza (rys. 10c, d). W procesie spawania laserowego $z$ materiałem dodatkowym uzyskuje się spoiny
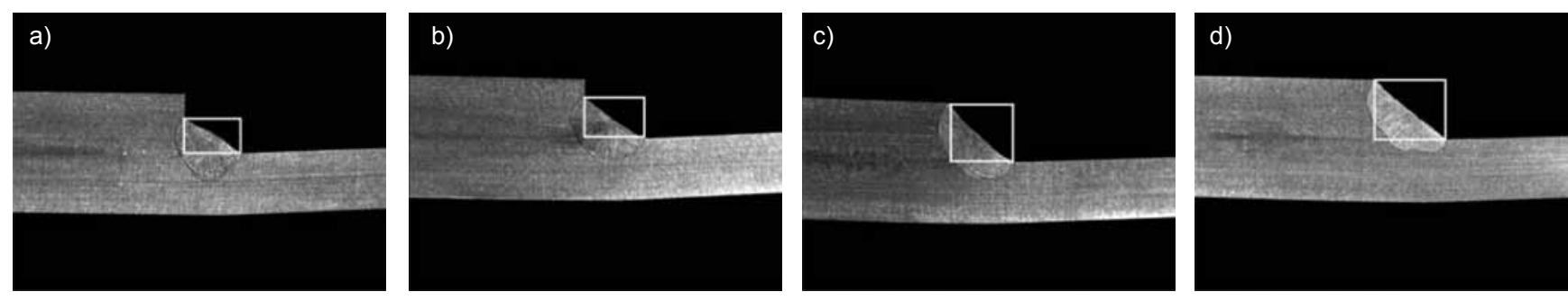

Rys. 10. Zmiany kształtu spoiny pachwinowej (asymetryczność) w procesie spawania laserowego z materiałem dodatkowym i taktylnym układem śledzenia złącza ALO3 w zależności od wartości bocznej siły docisku F (F1<F2<F3<F4). Materiał: X2CrNi18-9, grubość: 2 mm, spoiwo: G19 9 LSi, śred. - 1,2 mm: a) F1, b) F2, c) F3, d) F4

Fig. 10. Changes in the shape of fillet weld (asymmetry) in the process of laser welding with additional material and seam tracking system ALO3 of joint depending on the side clamping force $F(F 1<F 2<F 3<F 4)$. Material: $X 2 C r N i 18-9,2 \mathrm{~mm}$ thickness, weld metal: G19 9 LSi, dia. $1.2 \mathrm{~mm}$ : a) F1, b) F2, c) F3, d) F4 


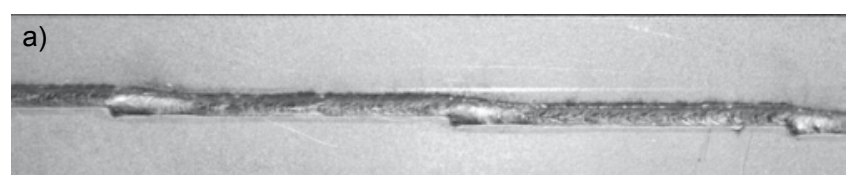

b)

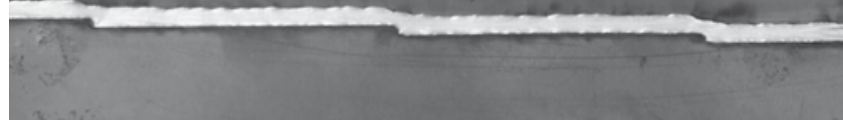

Rys. 11. Przykładowy wynik procesu śledzenia złącza zakładkowego ze skokową co $1 \mathrm{~mm}$ zmianą trajektorii osi złącza dla dwóch różnych procesów: a) lutospawania laserowego, b) spawania laserowego $z$ drutem

Fig. 11. Example result of the tracking of lap joint with $1 \mathrm{~mm}$ change in the trajectory of the axis of the joint for the two different processes: a) laser brazing, b) laser welding with wire

pachwinowe zazwyczaj niewielkich rozmiarów, a ich głównym kryterium odbiorowym, oprócz jakości, jest również estetyka wykonanych połączeń. System śledzenia złącza głowicy ALO3 jest przeznaczony do niwelowania łagodnych zmian trajektorii spoiny lub niewielkich zmian skokowych (prostopadłych do trajektorii) - ok. $1 \mathrm{~mm}$ (rys. 11). W przypadku większych i gwałtownych skokowych zmian trajektorii układ dociskowy drutu reaguje $z$ dynamiką zależną od ustawionej bocznej siły docisku oraz rodzaju prowadzonego procesu i jego parametrów (rys. 12). Ze względu na istotny wpływ bocznej siły docisku ustawianej w głowicy ALO3 na wynik procesu spawania, dynamika reakcji głowicy na znaczące zmiany trajektorii ruchu powinna być

\section{Podsumowanie}

Dostępność nowoczesnych typów laserów technologicznych o różnych mocach oraz specjalistycznych głowic laserowych do spawania ze spoiwem i lutospawania stwarzają możliwości konfigurowania i budowy zaawansowanych stanowisk do spajania tymi metodami różnorodnych materiałów. Zastosowanie układów z mechanicznym śledzeniem styku w przypadku obu tych procesów może rozszerzyć proces spajania $z$ wykorzystaniem lasera na nowe obszary w zakresie projektowania i przygotowania złączy do spajania.

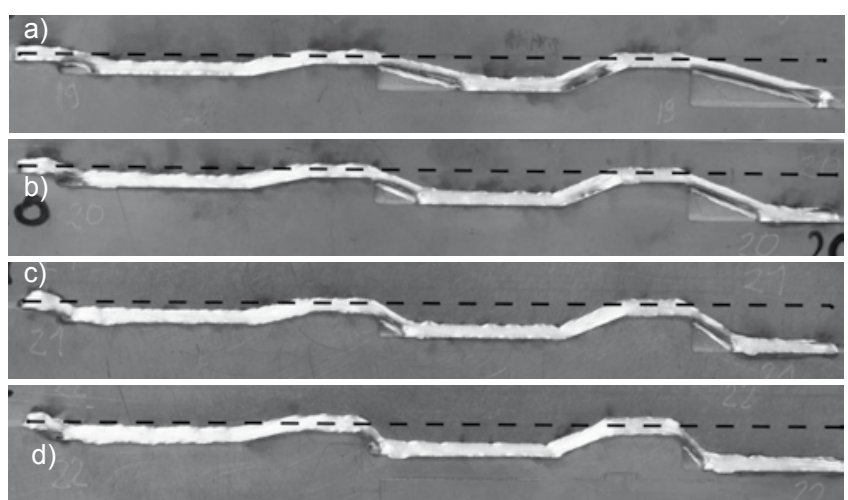

Rys. 12. Przykładowy wpływ wartości bocznej siły docisku F w przypadku spawania złączy zakładkowych ze stali nierdzewnej o grubości $2 \mathrm{~mm}(\mathrm{~F} 1<\mathrm{F} 2<\mathrm{F} 3<\mathrm{F} 4)$ : a) $F_{1}$, b) $\left.F_{2}, \mathrm{c}\right) \mathrm{F}_{3}$, d) $F_{4}$

Fig. 12. Example influence of the side camping force $F$ in the $2 \mathrm{~mm}$ thick stainless steel lap joints $(F 1<F 2<F 3<F 4)$ : a) $F_{1}$, b) $F_{2}$, c) $F_{3}$, d) $\mathrm{F}_{4}$

sprawdzana eksperymentalnie dla dobranych parametrów procesu przy różnych wartościach siły i różnej wielkości odchyłek trajektorii, tak aby zostały spełnione wymagania jakościowe w stosunku do całego złącza. Dodatkowo, odpowiednio dobrane parametry procesu powinny zapewniać zarówno płynne rozpoczęcie, jak i zakończenie procesu - odcięcie wiązką lasera zakończenia drutu z pozostawieniem odpowiedniej długości „wolnego wylotu drutu”, aby można było w cyklu automatycznym rozpocząć wykonanie kolejnych złączy.

Głowica spawalnicza ALO3 z dotykowym układem śledzenia złącza pozwala na zniwelowanie określonych niedokładności zestawienia i pozycjonowania elementów dla wybranych złączy spawanych. Uzyskanie poprawnych złączy jest zależne od rodzaju procesu (spawanie bądź lutospawanie) i zależy nie tylko od wielkości i geometrii odchyłek trajektorii styku, ale też od wielkości i właściwości fizycznych jeziorka roztopionego metalu, które są zależne od rodzaju materiałów dodatkowych oraz podstawowych parametrów procesu.

\section{Literatura}

[1] Brockmann R., Mann K.: Disk Lasers Enable Industrial Manufacturing - What Was Achieved and What Are the Limits? Laser Technik Journal, 2007, Vol. 4, No. 3, p. 50-53.

[2] Materiały reklamowe, materiały ofertowe i dokumentacja uradzeń firmy Trumpf www.trumpf-laser.com

[3] Scansonic, Scapacs $₫$ System Integration, Scansonic, Berlin, 2007.

[4] Staufer H., Ruhrnosl M., Miessbacher G.: LaserHybrid WeIding and LaseBrazing: State of the art in technology and practice by the examples of the Audi A8 and VW-Phaeton, Fronius International $\mathrm{GmbH}$, Wels Austria.

[5] Thomy C., Seefeld T., Vollertsen F.: Laser and laser-GMA weIding applications using High Power Fiber Laser, 1st international Fraunhofer workshop on fiber lasers, Fraunhofer IWS, Dresden, 22 November 2005.

[6] Trumpf $\mathrm{GmbH}+$ Co. KG. http://www.de.trumpf.com/produkte/ lasertechnik/ produkte/festkoerperlaser/scheibenlaser/trudisk. html. 10.05. 2010. 